\title{
Silica production in the Sargasso Sea during spring 1989
}

\author{
Mark A. Brzezinski , Carol A. Kosman \\ Department of Ecology, Evolution and Marine Biology, University of California, Santa Barbara, California 93106, USA
}

\begin{abstract}
Profiles of silicic acid, chlorophyll $a_{1}$ biogenic silica, and lithogenic silica concentrations and the rate of silica production were obtained from 7 depths in the upper 100 to $200 \mathrm{~m}$ at 8 stations in the western Sargasso Sea between May 7 and 18, 1989. Stations were distributed from the southern edge of the Gulf Stream to about $400 \mathrm{~km}$ south of Bermuda. An additional set of profiles was obtained at Stn S near Bermuda on March 28, 1989. Silicic acid concentrations in the euphotic zone were generally between 0.6 and $0.9 \mu \mathrm{M}$. Biogenic silica concentrations ranged from 7 to $1400 \mathrm{nmol} \mathrm{Si} \mathrm{l}^{-1}$ with concentrations $<50 \mathrm{nmol} \mathrm{Si}]^{-1}$ being typical of stations south of $35^{\circ} \mathrm{N}$ well away from the Gulf Stream and its eddies. Specific production rates of biogenic silica $\left(V_{\mathrm{b}}\right)$ averaged $0.16 \mathrm{~d}^{-1}$ (range: 0.01 to $0.67 \mathrm{~d}^{-1}$ ) corresponding to an average doubling time for the diatoms of $4.2 \mathrm{~d}$. Values of $V_{b}$ were lowest between 32 and $34^{\circ} \mathrm{N}$ with higher values observed both to the north and south. The doubling times of the diatom assemblages at stations south of $35^{\circ} \mathrm{N}(2$ to $20 \mathrm{~d})$, away from the Gulf Stream and its eddies, were in the same range as those reported for the picophytoplankton in the Sargasso Sea suggesting that diatoms can grow as fast as the more numerous picophytoplankton in oligotrophic oceans. Subsurface maxima in biogenic silica concentration, chlorophyll biomass and sllica production rates were observed near the top of the nitracline at 7 of the 9 stations. Integrated silica production rates between the surface and the $0.1 \%$ light depth were generally between 0.2 and $0.7 \mathrm{mmol} \mathrm{Si} \mathrm{m} \mathrm{m}^{-2} \mathrm{~d}^{-1}$ with an average of $47 \%$ of that production occurring within the nitracline. If diatoms taking up silicic acid within the nitracline also utilize nitrate, they may account for between 0.56 and $0.84 \mathrm{~mol} \mathrm{C} \mathrm{m}^{-2} \mathrm{yr}^{-1}$ of new production which is 16 to $24 \%$ of the estimated annual total new production for the region
\end{abstract}

KEY WORDS: Diatoms · Nutrients - Silicic acid · Silicon · Silica production

\section{INTRODUCTION}

Recent data indicate that the importance of diatoms to the biogeochemical cycling of elements in the ocean extends beyond the coastal waters to the open sea. During the JGOFS North Atlantic bloom study a diatom bloom developed that appeared to sink en masse out of the surface waters following significant depletion of nitrate and silicic acid in the euphotic zone (Sieracki et al. 1993). Data from a time-series study of silica cycling at the JGOFS Bermuda Atlantic Times Series (BATS) site indicate that diatoms account for 13 to $26 \%$ of the annual primary production and up to $30 \%$ of the annual new production in the oligotrophic

•E-mail: brzezins@lifesci.ucsb.edu waters of the western Sargasso Sea (Brzezinski \& Nelson 1995, Nelson \& Brzezinski 1996). Diatoms are also important in the export of biological materials at time-series station ALOHA in the subtropical north Pacific Ocean (Karl et al. 1996).

The importance of diatoms in the open sea is masked by their low abundance in the phytoplankton and the lack of diatom opal in the underlying sediments. Nevertheless, the available data suggest that silica production in the surface waters of those systems is significant in global terms (Nelson et al. 1995). For example, the annual rate of silica production at the BATS site $\left(240 \mathrm{mmol} \mathrm{m}{ }^{-2} \mathrm{yr}^{-1}\right.$; Nelson \& Brzezinski 1996 ), is only $3 \%$ of the annual silica production rate ( $8300 \mathrm{mmol} \mathrm{m}^{-2} \mathrm{yr}^{-1}$ ) estimated for the major coastal upwelling zones by Nelson et al.; (1995). However, extrapolation of the annual silica production rates off 
Bermuda over the vast area of all mid-ocean gyres results in an integrated silica production rate for those oligotrophic systems that equals the combined silica production occurring in all regions overlying the major zones of modern global siliceous sediment accumulation (Nelson \& Brzezinski 1996). While such estimates are provocative, they are based on so few data with such limited spatial coverage that the conclusions are subject to large uncertainties.

Refining our understanding of the silica cycle of the oligotrophic mid-ocean gyres will require additional data on the magnitude and timing of oceanic diatom blooms. Blooms of large diatoms appear to be responsible for the mid-summer peak in total particle export at Station ALOHA in the subtropical Pacific near Hawaii (Karl et al. 1996). In the Sargasso Sea off Bermuda a diatom bloom occurs each winter or spring that supports ca 30 to $50 \%$ of the annual export of biogenic silica from the upper $150 \mathrm{~m}$ (Brzezinski \& Nelson 1995, Nelson \& Brzezinski 1996). The importance of diatom blooms to biogeochemical processes may be greater in other regions of the Sargasso Sea than they are near Bermuda. Diatom abundances during spring blooms to the northwest of Bermuda near the Gulf Stream can be several orders of magnitude greater than at the BATS site (Hulburt 1990), but the contribution of diatoms to elemental cycles across the gyre has not been examined.

Here we report the first measurements of silica production rates across a reasonably large area (ca $0.5 \times$ $10^{6} \mathrm{~km}^{2}$ j of the western Sargasso Sea during the spring of 1989. Our goals were to determine the levels of silica production across the gyre during the spring bloom period and to assess the possible contribution of diatoms to new production.

\section{MATERIALS AND METHODS}

Profiles of silicic acid $\left(\mathrm{Si}(\mathrm{OH})_{4}\right)$, biogenic silica $\left(\mathrm{BSiO}_{2}\right)$ and lithogenic silica $\left(\mathrm{LSiO}_{2}\right)$ concentrations and silica production rates were obtained from 7 depths in the upper 100 to $200 \mathrm{~m}$ at 8 stations in the western Sargasso Sea between ivay 7 and 18,1989 , aboard the RV 'Oceanus' with an additional set of profiles obtained earlier from Stn S near Bermuda on March 28, 1989, aboard the RV 'Weatherbird I'. Water samples were collected using acid-washed 101 Go-Flo bottles. Sampling depths were chosen based on profiles of photosynthetically active radiation (PAR) determined using a LICOR ${ }^{\circledast}$ spherical quantum sensor Samples were collected from depths corresponding to $100,60,25$. $10,2.5,1$ and $0.1 \%$ of the value of PAR measured just below the sea surface $\left(I_{0}\right)$. The concentrations of chlorophyll a (chl a) and nitrate were measured at sea according to Strickland \& Parsons (1972).
Samples for the analysis of silicic acid concentration, $\left[\mathrm{Si}(\mathrm{OH})_{4}\right]$, were drained directly from the Go-Flo botties into polypropylene containers and analyzed at sea using the method of Brzezinski \& Nelson (1995). That method has a detection limit of $50 \mathrm{nmol} \mathrm{l}^{-1}$ $\mathrm{Si}(\mathrm{OH})_{4}$ when used with a $10 \mathrm{~cm}$ cuvette. Additional 11 samples were collected for the analysis of biogenic and lithogenic silica concentrations, $\left[\mathrm{BSiO}_{2}\right]$ and $\left[\mathrm{LSiO}_{2}\right]$ respectively. Each of those samples was filtered through a $0.6 \mu \mathrm{m}$ polycarbonate filter, the filters folded in quarters and placed in separate polystyrene petri dishes. The filters were then dried at $65^{\circ} \mathrm{C}$ and stored at room temperature. The particulate matter on each filter was later analyzed for both $\left[\mathrm{BSiO}_{2}\right]$ and $\left[\mathrm{LSiO}_{2}\right]$ using the $\mathrm{NaOH} / \mathrm{HF}$ digestion sequence outlined by Brzezinski \& Nelson (1995). The biogenic and lithogenic silica concentration analyses each had a detection limit of $0.5 \mathrm{nmol} \mathrm{Si} \mathrm{l}^{-1}$.

Silica production rates were determined using the ${ }^{30} \mathrm{Si}$ tracer method of Nelson \& Goering (1977). A 2.81 polycarbonate bottle was filled from each Go-Flo bottle and a $0.25 \mu \mathrm{M}$ tracer addition was made to each sample. Each sample bottle was then covered with a neutral density screen to simulate the in situ light intensity at the depth where the enclosed water was collected and placed in a deckboard incubator. Water temperature in the incubator was maintained by flowing surface seawater After a 6 to $9 \mathrm{~h}$ incubation the particulate silica in each sample was collected on a $0.6 \mu \mathrm{m}$ polycarbonate filter and stored as described above for the particulate silica samples. The isotopic composition of the silica on each filter was determined by conversion to $\mathrm{BaSiF}_{6}$ (Nelson \& Goering 1977) followed by mass spectrometry using a Measurement and Analysis Systems 6-60 mass spectrometer. Three micromoles of ${ }^{29} \mathrm{Si}\left(95.65\right.$ atom $\%{ }^{29} \mathrm{Si}$ ) was added to each sample as carrier. The range in the atom $\%{ }^{30} \mathrm{Si}$ for triplicate analyses of the same sample was 0.002 .

The low concentrations of biogenic silica present in

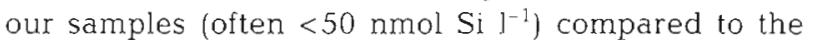
much larger mass of ${ }^{29} \mathrm{Si}$ carrier $(3 \mu \mathrm{mol})$ added when preparing samples for isotopic analysis resulted in very low enrichments of ${ }^{30} \mathrm{Si}$ of the sample/carrier mixtures. A sample was considered significantly enriched in ${ }^{30} \mathrm{Si}$ when the atom $\%{ }^{30} \mathrm{Si}$ of the raw mass spectrum was $\geq 0.004$ atom \% (i.e. twice the observed range for triplicate analyses of the same sample) greater than that produced by an unenriched sample of equal mass. For example, the 2.81 samples used in our experiments typically contained about $100 \mathrm{nmol}$ of particulate silica (sum of $\mathrm{BSiO}_{2}$ and $\mathrm{LSiO}_{2}$ ). A mixture of $100 \mathrm{nmol}$ of isotopically natural $\mathrm{Si}\left(\right.$ atom $\%{ }^{30} \mathrm{Si}=3.119$ on our instrument) and $3 \mu \mathrm{mol}$ of carrier $\left(0.230\right.$ atom $\%{ }^{30} \mathrm{Si}$ on our instrument) would have a measured atom $\%{ }^{30} \mathrm{Si}$ of 0.323 . The same mixture would be considered to 
be enriched in ${ }^{30} \mathrm{Si}$ relative to natural Si for values $\geq 0.327$ atom $\%{ }^{30} \mathrm{Si}$. All of our analyses met this criterion. The atom $\%{ }^{30} \mathrm{Si}$ in the raw mass spectrum from each sample exceeded that for an unenriched sample of equal sample mass by an average of 0.027 atom \% ${ }^{30} \mathrm{Si}$, or $0.027 / 0.004=6.75$ times the analytical uncertainty of the measurement. Thus, the reported rates are subject to an average analytical error of $1 / 6.75=15 \%$.

The production rate of biogenic silica $(\rho$, in nmol Si $\left.\mathrm{l}^{-1} \mathrm{~d}^{-1}\right)$ and the specific rate of silica production $(V$, in $\mathrm{d}^{-1}$ ) were calculated from the mass spectrum from each sample according to the equations of Nelson \& Goering (1977). The resulting values of $V$ are normalized to the sum of biogenic and lithogenic phases and thus underestimate the specific rate of biogenic silica production, $V_{\mathrm{b}}$ by diatoms. $V_{\mathrm{b}}$ was calculated from $V$ using:

$$
V_{\mathrm{b}}=V \frac{\left[\mathrm{BSiO}_{2}\right]+\left[\mathrm{LSiO}_{2}\right]}{\left[\mathrm{BSiO}_{2}\right]}
$$

The presence of non living biogenic silica (empty frustules, shell fragments, etc.) will cause $V_{\mathrm{b}}$ to be an underestimate of the specific rate of uptake by living diatoms because it is normalized to total biogenic silica, which includes some unknown fraction of detrital material. In contrast, the increase in ambient $\left[\mathrm{Si}(\mathrm{OH})_{4}\right]$ caused by our tracer addition may have increased $V_{b}$ above that occurring in situ. Kinetic studies of the concentration dependence of silicic acid uptake over 2 yr at the JGOFS BATS site showed a proportional increase in $V_{b}$ with increasing $\left[\mathrm{Si}(\mathrm{OH})_{4}\right.$ ] over the 0.5 to $2.5 \mu \mathrm{M}$ range (Brzezinski \& Nelson 1996). Assuming that the diatom assemblages we sampled had similar kinetics to those at the BATS site our $0.25 \mu \mathrm{M} \mathrm{Si}(\mathrm{OH})_{4}$ tracer addition to water with ambient $\left[\mathrm{Si}(\mathrm{OH})_{4}\right]$ of 0.6 to $1.2 \mu \mathrm{M}$ would have increased $V_{b}$ by ca 20 to $30 \%$. The extent to which the opposing effects of the presence of detrital biogenic silica and the increase in $\left[\mathrm{Si}(\mathrm{OH})_{4}\right]$ caused by the addition of tracer cancel each other cannot be evaluated.

\section{RESULTS}

The 9 stations were distributed within an approximate $0.5 \times 10^{6} \mathrm{~km}^{2}$ area of the western Sargasso Sea and included locations ranging from the southern edge of the Gulf Stream to ca $400 \mathrm{~km}$ south of Bermuda (Fig. 1). Examination of the station locations relative to sea surface temperature indicates that all stations north of $35^{\circ} \mathrm{N}$ were likely influenced by the Gulf Stream (Fig. 1). Stns 2, 3 and 13 were at the southern edge of the Gulf Stream (Fig. 1). The proximity of those stations to the Gulf Stream suggests that the data obtained at them are not representative of the Sargasso Sea proper. We thus consider only those stations located south of $35^{\circ} \mathrm{N}$ to be indicative of conditions within the gyre.

Profiles of each property showed many consistent features among stations. Profiles from a representative station are presented in Fig. 2. The location of this station $\left(31^{\circ} 46^{\prime} \mathrm{N}, 64^{\circ} 07^{\prime} \mathrm{W}\right)$ is very near the JGOFS BATS site $\left(31^{\circ} 50^{\prime} \mathrm{N}, 64^{\circ} 10^{\prime} \mathrm{W}\right)$ and is well away from the Gulf Stream. The surface mixed layer was about $20 \mathrm{~m}$ deep with a gradual seasonal thermocline (Fig. 2).
Fig. 1. Station locations (0) within the northwestern Sargasso Sea Position of Gulf Stream (GS) and cold-core eddies (CE) taken from NOAA/National Weather Service analyses between May 9 and 18 1989

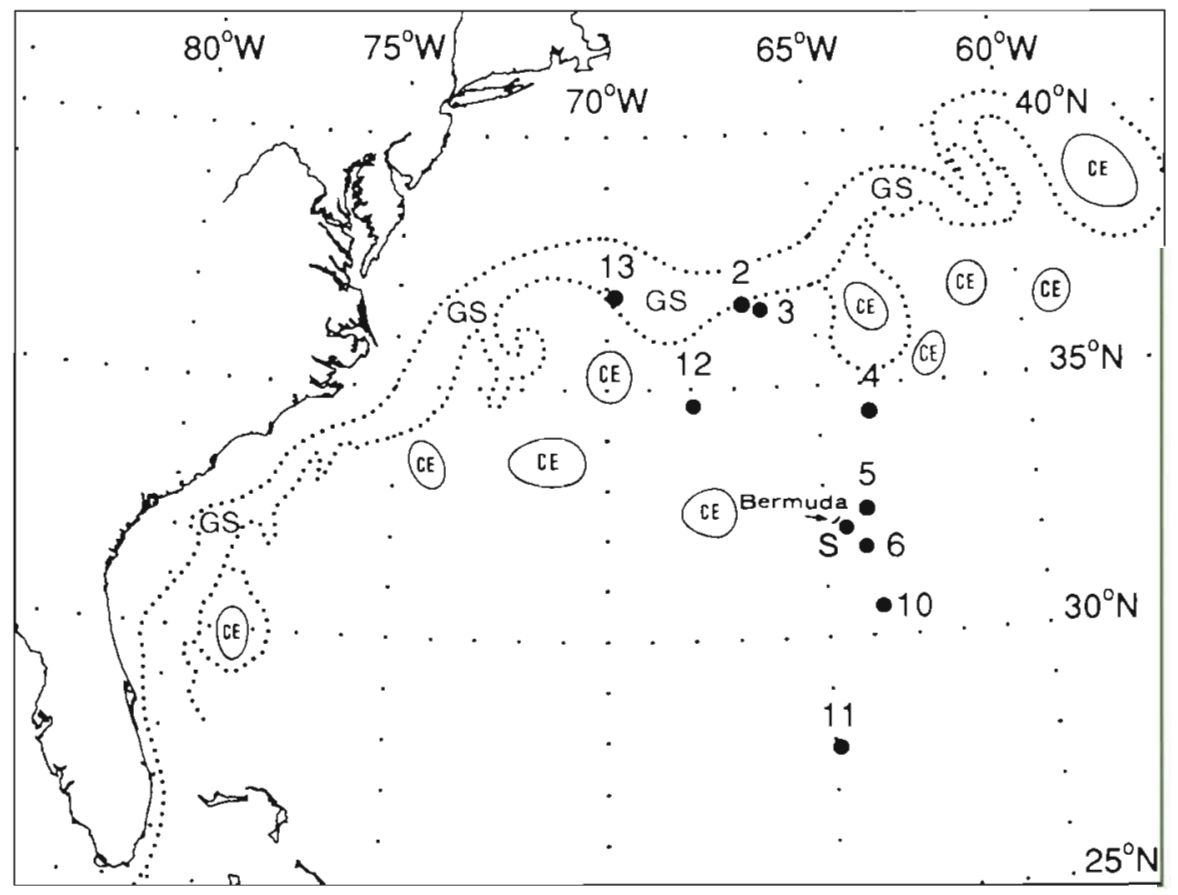




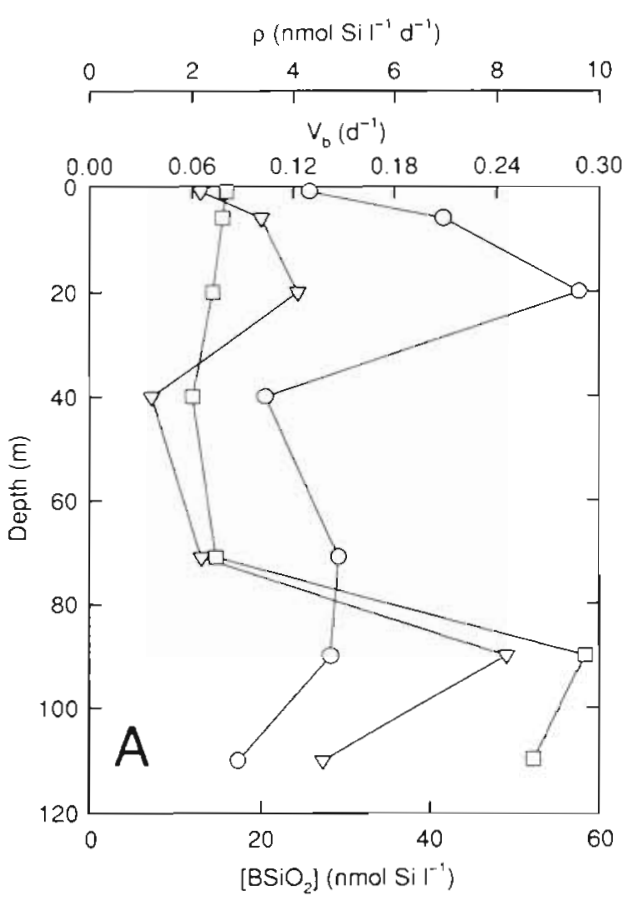

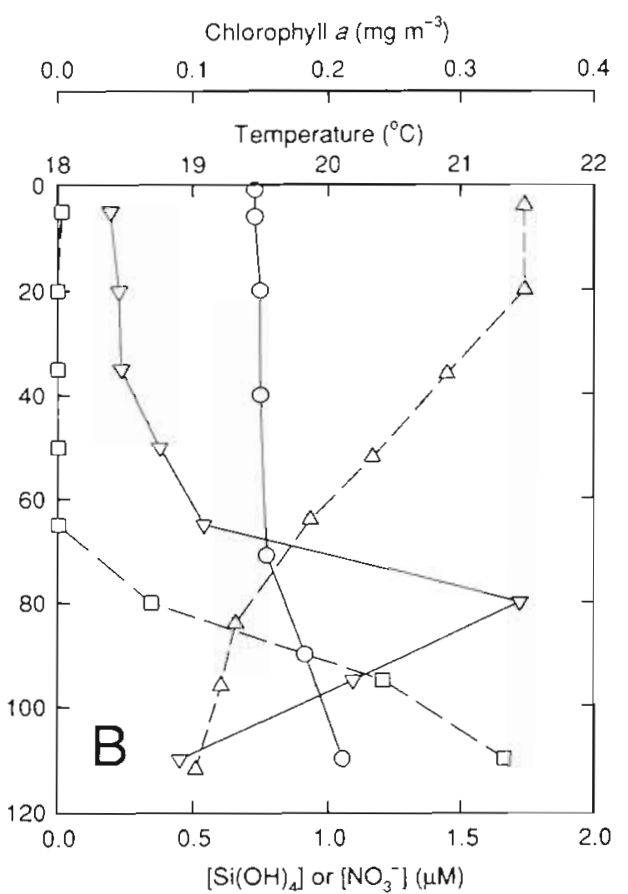

Fig. 2. Vertical profiles from Stn 6 near the BATS site. (A) Specific production rates of biogenic silica, $V_{\mathrm{b}}$ (O); biogenic silica concentrations, $\left[\mathrm{BSiO}_{2}\right](\square)$; and silica production rates, $\rho$ $(\nabla)$ (B) Chlorophyll a concentration $(\nabla)$; temperature $(\Delta)$; nitrate concentration, $\left[\mathrm{NO}_{3}{ }^{-}\right](\square)$; silicic acid concentration, $\left[\mathrm{Si}(\mathrm{OH})_{4}\right](\mathrm{O})$
That temperature profile was typical of the stratification observed at all other sites where the depth of the mixed layer ranged from 15 to $20 \mathrm{~m}$. Nitrate was undetectable (i.e. $\leq 0.05 \mu \mathrm{M}$ ) in the upper 60 to $80 \mathrm{~m}$ at all sites, while the concentrations of $\mathrm{Si}(\mathrm{OH})_{4}$ were generally between 0.6 and $0.9 \mu \mathrm{M}$ over that same depth zone (Fig. 2). Stn 13 in the Gulf Stream was exceptional in that $\left[\mathrm{Si}(\mathrm{OH})_{4}\right]$ was $1.2 \mu \mathrm{M}$ throughout the surface layer The coincidence of the gradients of $\left[\mathrm{NO}_{3}{ }^{-}\right]$and $\left[\mathrm{Si}(\mathrm{OH})_{4}\right]$ within the nutricline that is evident in Fig. 2 occurred at all stations. $\mathrm{BSiO}_{2}$ concentrations ranged from 7 to $1400 \mathrm{nmol} \mathrm{Si} l^{-1}$ in the euphotic zone. The greatest concentrations were observed at stations north of $35^{\circ} \mathrm{N}$ with lower concentrations, generally $<50 \mathrm{nmol}$ $\mathrm{Si} \mathrm{l}^{-1}$, found south of that latitude. Subsurface maxima in both $\left[\mathrm{BSiO}_{2}\right]$ and chlorophyll were present near the top of the nitracline (Fig. 2) at all stations except Stns S and 3.

Siliceous biomass levels in the gyre were generally much lower than ambient silicic acid concentrations. The ratio of integrated silicic acid concentrations. $\int\left[\mathrm{Si}(\mathrm{OH})_{4}\right]$, to integrated concentrations of $\mathrm{BSiO}_{2}$, $\int\left[\mathrm{BSiO}_{2}\right]$, averaged 38 (range: 6 to 76 ) for stations south of $35^{\circ} \mathrm{N}$ and 7.8 (range: 0.5 to 19 ) for the 3 stations north of $35^{\circ} \mathrm{N}$ (Table 1). Stn 2 near the Gulf Stream (Fig. 1) was the only station where $\int\left[\mathrm{Si}(\mathrm{OH})_{4}\right]:\left[\left[\mathrm{BSiO}_{2}\right]\right.$ was less than 1 (Table 1 ). Values of $\int\left[\mathrm{BSiO}_{2}\right]$ were greatest north of $35^{\circ} \mathrm{N}$, while $\int\left[\mathrm{BSiO}_{2}\right]$ south of that latitude were all $\leq 7.3$ and often $<3 \mathrm{mmol} \mathrm{m}^{-2}$ without a discernable latitudinal trend (Table 1, Fig 1). Integrated lithogenic silica concentrations, $\int\left[\mathrm{LSiO}_{2}\right]$, were generally $<3 \mathrm{mmol} \mathrm{m}^{-2}$ at all stations (Table 1 )
Specific production rates of biogenic silica were quite high despite the low levels of siliceous biomass. Values of $V_{b}$ ranged from 0.014 to $0.67 \mathrm{~d}^{-1}$, averaging $0.164 \mathrm{~d}^{-1}$, corresponding to a mean doubling time for the diatom assemblages of $4.2 \mathrm{~d}$ (range: 1.0 to $50 \mathrm{~d}$ ). Generally $V_{b}$ decreased with depth (Fig 2), but silica production continued well into the nitracline at all stations. The average value of $V_{b}( \pm S D)$ within the nitracline $\left(0.056 \pm 0.041 \mathrm{~d}^{-1}\right)$ was about a third of that for the overlying water $\left(0.185 \pm 0.137 \mathrm{~d}^{-1}\right)$. Significant values of $V_{b}$ were observed at the deepest depth sampled $\left(0.1 \% I_{0}\right.$; Fig. 2$)$ at all stations indicating that we never sampled the full depth range of surface silica production. Thus, integrated silica production rates are minimum estimates for the upper water column.

The average $V_{b}$ between the surface and the $0.1 \%$ $I_{0}$ varied 9 -fold among stations. Lowest values were generally found between 32 and $34^{\circ} \mathrm{N}$ with higher values observed both to the north and south (Table 1). The highest rates were observed at the 2 southernmost stations (10 and 11; Table 1) well away from the influence of the Gulf Stream and cold-core eddies. Siliceous biomass was low at those sites (Table 1), but the doubling times of the resident diatom assemblages were rapid (ca $2 \mathrm{~d}$ in each case).

Silica production rates $(\rho)$ averaged $6.3 \mathrm{nmol} \mathrm{Si} \mathrm{l}^{-1} \mathrm{~d}^{-1}$ (range: 1.2 to $31.0 \mathrm{nmol} \mathrm{Si}^{-1} \mathrm{~d}^{-1}$ ). Subsurface maxima in $\rho$ were observed at the base of the euphotic zone coincident with the chl a maximum and the nitracline (Fig. 2) at all stations except Stns 3 and 13 located within the Gulf Stream or near its eddies (silica production rates were not measured at Stn 2 which was also near or in the 
Table 1 . Depth of the $0.1 \%$ light, integrated chlorophyll, silicic acid, biogenic silica and lithogenic silica concentrations, and silica production rates in the Sargasso Sea during May 1989. Parameters integrated to the 0.1\% light depth. Dashes denote lack of data

\begin{tabular}{|c|c|c|c|c|c|c|c|c|c|}
\hline Latitude & Station & $\begin{array}{c}0.1 \% I_{0} \\
(\mathrm{~m})\end{array}$ & $\int_{\left(\mathrm{mg} \mathrm{m} \mathrm{m}^{-2}\right)}^{[\mathrm{chl} a]}$ & $\underset{\left(\mathrm{mmol} \mathrm{m} \mathrm{m}^{-2}\right)}{\int\left[\mathrm{Si}(\mathrm{OH})_{4}\right.}$ & $\underset{\left(\mathrm{mmol} \mathrm{m} \mathrm{m}^{-2}\right)}{\int\left[\mathrm{BSiO}_{2}\right]}$ & $\underset{\left(\mathrm{mmol} \mathrm{m} \mathrm{m}^{-2}\right)}{\int\left[\mathrm{LSiO}_{2}\right]}$ & $\operatorname{Mean}_{\left(\mathrm{d}^{-1}\right)} V_{\mathrm{b}}$ & $\left.\int_{(\mathrm{m} m o l} \mathrm{m}^{-2} \mathrm{~d}^{-1}\right)$ & $\begin{array}{l}\% \text { of } \int_{p} \text { occurring } \\
\text { within nutracline }\end{array}$ \\
\hline $36^{\circ} 51^{\prime} \mathrm{N}$ & 13 & 119 & 20.3 & 126.3 & 6.6 & 2.0 & 0.144 & 0.67 & 48 \\
\hline $36^{\circ} 39^{\prime} \mathrm{N}$ & 2 & $-{ }^{a}$ & 23.8 & 52.1 & 109.1 & 2.7 & - & - & - \\
\hline $36^{\circ} 33^{\prime} \mathrm{N}$ & 3 & 95 & 19.6 & 78.8 & 20.5 & 2.9 & 0.081 & 1.48 & 28 \\
\hline $34^{\circ} 40^{\prime} \mathrm{N}$ & 12 & $-c$ & - & 82.8 & - & - & $0.070^{\mathrm{b}}$ & - & - \\
\hline $34^{\circ} 27^{\prime} \mathrm{N}$ & 4 & 119 & 24.8 & 76.0 & 12.5 & 2.0 & 0.058 & 0.51 & 67 \\
\hline $32^{\circ} 32^{\prime} \mathrm{N}$ & 5 & $-a$ & 15.7 & 102.0 & 2.1 & 3.2 & - & - & - \\
\hline $32^{\circ} 10^{\prime} \mathrm{N}$ & S & 80 & - & 55.9 & 7.3 & 2.0 & 0.031 & 0.24 & 40 \\
\hline $31^{\circ} 46^{\prime} \mathrm{N}$ & 6 & 110 & 13.7 & 88.9 & 2.8 & 2.1 & 0.158 & 0.40 & 56 \\
\hline $30^{\circ} 35^{\prime} \mathrm{N}$ & 10 & 110 & 7.6 & 90.0 & 1.5 & 1.9 & 0.341 & 0.46 & c \\
\hline \multirow[t]{2}{*}{$27^{\circ} 50^{\prime} \mathrm{N}$} & 11 & 180 & 27.1 & 159.8 & 2.1 & 2.7 & 0.341 & 0.73 & 44 \\
\hline & Means & 116 & 20.0 & 92.2 & 18.3 & 2.4 & 0.165 & 0.64 & 47 \\
\hline \multicolumn{10}{|c|}{$\begin{array}{l}{ }^{a} \text { Light data unavailable. Integration depths are } 105,115 \text { and } 125 \mathrm{~m} \text { for Stns } 2,5 \text { and } 12 \text {, respectively } \\
{ }^{\circ} V_{b} \text { measured at } 2 \mathrm{~m} \text { only on March } 28,1989 \text {, corresponding } \rho=1.2 \mathrm{nmol} \mathrm{Si} \mathrm{l}^{-1} \mathrm{~d}^{-1} \text {. Data from this station are not included } \\
\text { in the reported averages } \\
{ }^{c} \text { All samples for silica production taken above the depth of the nitracline at this site, } 135 \mathrm{~m}\end{array}$} \\
\hline
\end{tabular}

Gulf Stream). Values of $\rho$ in those subsurface maxima at the base of the euphotic zone ranged from 5 to $8 \mathrm{nmol} \mathrm{Si}$ $\mathrm{I}^{-1} \mathrm{~d}^{-1}$. At Stns 3 and 13 in the Gulf Stream $\rho$ was maximal at the surface and decreased with depth.

Integrated production rates, $\int \rho$, between the surface and the $0.1 \%$ light depth were generally between 0.2 and $0.7 \mathrm{mmol} \mathrm{m}^{-2} \mathrm{~d}^{-1}$ (Table 1). The spatial variation in $\int \rho$ paralleled that of $V_{b}$ with lowest values occurring between 32 and $34^{\circ} \mathrm{N}$ with rates increasing to the north and south. An exceptionally high value of $1.48 \mathrm{mmol} \mathrm{Si}$ $\mathrm{m}^{-2} \mathrm{~d}^{-1}$ was observed at Stn 3 near the Gulf Stream primarily due to the relatively high biogenic silica concentrations present at this site (Table 1). An average of $47 \%$ (range: 28 to $67 \%$ ) of the silica production occurring between the surface and the $0.1 \%$ light depth was taking place within the nitracline (Table 1). That is a minimum estimate of the fraction of silica production occurring within the nitracline since silica production continued past the deepest depth sampled (see above).

\section{DISCUSSION}

The present data set constitutes the first study of silica cycling using isotopic tracers across a reasonably broad geographic region of a mid-ocean gyre. The only other examination of silica cycling in the Sargasso Sea or any other mid-ocean gyre is a time-series study at a single location conducted as part of the JGOFS BATS program (Brzezinski \& Nelson 1995, Nelson \& Brzezinski 1996). The results from our spatial survey indicate that several features of the silica cycle observed at the BATS site are common throughout much of the western Sargasso Sea. The concentrations of silicic acid we measured within the surface layer at stations well away from the influence of the Gulf Stream (0.6 to $0.9 \mu \mathrm{M})$ were in the same narrow range observed at the BATS site under stratified conditions (Michaels et al. 1994, Brzezinski and Nelson 1995). Both data sets show that $\mathrm{Si}(\mathrm{OH})_{4}$ is not depleted to nanomolar levels, as is nitrate, and its concentration often exceeds that of $\mathrm{BSiO}_{2}$ by over an order of magnitude. The coincidence of the top of the gradients in $\left[\mathrm{NO}_{3}{ }^{-}\right]$and $\left[\mathrm{Si}(\mathrm{OH})_{4}\right]$ that we observed across the gyre during May confirms observations from the BATS site that these 2 nutrients are depleted to similar depths early in the year (Brzezinski \& Nelson 1995).

Although our study was conducted during spring we did not encounter a well developed diatom bloom at any of our stations. Diatom blooms occur in the Sargasso Sea annually following winter convective mixing, but their timing is highly variable. Blooms documented at the BATS site over 6 yr occurred as early as January or as late as April with $\int\left[\mathrm{BSiO}_{2}\right]$ between 7.3 and $56.6 \mathrm{mmol} \mathrm{m}^{-2}$ (Brzezinski \& Nelson 1995). We observed $\int\left[\mathrm{BSiO}_{2}\right]$ of that magnitude at Stns 3,4 and 12 near the Gulf Stream and at Stn $S$ (Table 1) near Bermuda. However, values of $V_{b}$ at each of these stations were relatively low indicating that if blooms were present they were in decline. With the exception of Stn S, all stations south of $35^{\circ} \mathrm{N}$ had biomass levels much lower than typically associated with the winter/ spring diatom bloom at the BATS site (Table 1). That low biomass appeared to be actively growing at Stns 10 and 11 where the average $V_{\mathrm{b}}$ suggested doubling times of $2 \mathrm{~d}$ for the diatoms, but little siliceous biomass had accumulated in the surface waters.

The values of $V_{b}$ that we observed in an oligotrophic gyre were similar to rates reported from more eutrophic systems suggesting that diatoms in the Sargasso Sea 
can have growth rates similar to their counterparts in more fertile waters. The average values of $V_{b}$ we observed ranged from ca 0.03 to $0.34 \mathrm{~d}^{-1}$ with an overall mean of 0.17 (Table 1). Values from coastal upwelling zones can exceed $1.4 \mathrm{~d}^{-1}$, but values of $V_{\mathrm{b}}$, of about $0.3 \mathrm{~d}^{-1}$ are more typical (Nelson \& Goering 1978). Values of $V_{0}$ from the Bering Sea and Southern Ocean. are generally <0.1 $\mathrm{d}^{-1}$ (e.g. Banahan \& Goering 1986, Nelson \& Smith 1986). Even after the possible 20 to $30 \%$ increase in $V_{\mathrm{b}}$ caused by our tracer addition is taken into account (see 'Methods'), our estimated doubling times suggest the growth rates of diatoms in oligotrophic mid-ocean gyres can approach those in upwelling zones and may exceed those in polar waters.

Estimated doubling times for diatoms south of $35^{\circ} \mathrm{N}$ corresponded to division rates of between 0.05 and 0.5 divisions $\mathrm{d}^{-1}$. Those rates are similar to division rates for the entire phytoplankton assemblage of 0.019 to 0.61 divisions $\mathrm{d}^{-1}$ estimated for the BATS site (ca $32^{\circ} \mathrm{N}$ ) by Michaels et al. (1994) using ${ }^{14} \mathrm{C}$ productivity data. Since the biomass and productivity of oceanic waters is typically dominated by picophytoplankton (e.g. Mal one 1980. Murphy \& Haugen 1985, Chisholm et al. 1988) the doubling time derived from the ${ }^{14} \mathrm{C}$ data probably most strongly reflects that of those small cells, while the doubling times calculated from our ${ }^{30} \mathrm{Si}$ tracer experiments represent the growth of diatoms which are typically larger than picophytoplankton. The similarity between the doubling times estimated from ${ }^{14} \mathrm{C}$ and ${ }^{30} \mathrm{Si}$ tracers suggests that diatoms in the open sea can have growth rates similar to those of the more abundant picophytoplankton.

In contrast to the relatively high values of $V_{b}$ observed in the gyre, values of $\int \rho$ with mean $0.6 \mathrm{mmol} \mathrm{Si} \mathrm{m} \mathrm{m}^{-2} \mathrm{~d}^{-1}$ were at about 2 orders of magnitude lower than observed in coastal upwelling systems (ca $50 \mathrm{mmol} \mathrm{Si}$ $\mathrm{m}^{-2} \mathrm{~d}^{-1}$; Nelson \& Goering 1977, 1978, Nelson et al. 1981), in the Bering Sea and in the Southern Ocean (ca $20 \mathrm{mmol} \mathrm{Si} \mathrm{m}{ }^{-2} \mathrm{~d}^{-1}$ in both; e.g. Nelson \& Gordon 1982, Banahan \& Goering 1986, Nelson \& Smith 1986 , Leynaert et al. 1993). The low values of $\int \rho$ in the Sargasso Sea result mainly from the low siliceous biomass ( $<50 \mathrm{nM}$ ) in the gyre. Mantenance ot such low levels of silica production and siliceous biomass despite relative rapid diatom growth suggests significant grazing and/or silica dissolution in the upper water column. Data on diatom mortality due to grazing are not available, but the fraction of silica production that dissolves in the upper $150 \mathrm{~m}$ of the Sargasso Sea has been estimated to be between 50 and $80 \%$ (Brzezinski \& Nelson 1995. Nelson \& Brzezinski 1996).

Integrated silica production rates exhibited a high degree of spatial variability. The spatial variability in $\int \rho$ we observed encompasses the entire range of values observed over a period of $3 \mathrm{yx}$ at the BATS site (Nelson
\& Brzezinski 1996). Integrated silica production rates from our quasi-synoptic study range from 0.2 to 1.5 mmol Si $\mathrm{m}^{-2} \mathrm{~d}^{-1}$ with a mean value of 0.6 , while those from the BATS site range from 0.1 to $0.9 \mathrm{mmol} \mathrm{Si} \mathrm{m} \mathrm{m}^{-2}$ $\mathrm{d}^{-1}$ with an average rate of 0.4 (Nelson \& Brzezinski 1996). The time course data from the BATS site show no seasonal trend in $\int \rho$ with large fluctuations on times scales of 3 to 5 d (Nelson \& Brzezinski 1996). Thus, silica production in the Sargasso Sea during non-bloom periods is characterized by both high spatial and high temporal variability. A strong seasonal maximum in silica production may occur during the winter/spring diatom bloom, but no measurements of the rate of silica production during blooms are available. The order of magnitude increase in $\left[\mathrm{BSiO}_{2}\right]$ during those events (Brzezinski \& Nelson 1995) does suggest significantly higher rates of silica production during blooms than observed at other times of the year.

Our observation that about half of the silica production in the upper water column occurs within the nitracline supports the hypothesis that diatoms growing near the base of the euphotic zone may be responsible for a significant amount of new production in stratified oligotrophic gyres (Goldman 1988, 1993). Light intensities within the nitracline ( 80 to $120 \mathrm{~m}$ ) can reach 5 to $30 \mu \mathrm{E} \mathrm{m}^{-2} \mathrm{~s}^{-1}$ for several hours each day (Knap et al. 1992,1993 ) which is sufficient to support the growth of a number of diatom species with $\mathrm{NO}_{3}{ }^{-}$as the sole $\mathrm{N}$ source (Goldman 1993 and references therein). Moreover, direct measurements of nitrate uptake within the nitracline show significant nitrate use in this depth zone during both day and night (F. Lipschultz pers. comm.). It is thus possible that the silica production we observed in the nitracline is at least partially attributable to diatoms taking up nitrate.

Silica production within the nitracline occurred at all stations, spanning nearly 10 degrees of latitude, indicating that the phenomena is common across the western Sargasso Sea. A re-analysis of the time course of silica production rates of Nelson \& Brzezinski (1996) obtained at the JGOFS BATS site shows that silica production within the nitracline also persists throughout the year. Their measurements show that sllica production occurred to at least $160 \mathrm{~m}$ on 12 cruises spanning several seasons over 3 yr with the diatoms below about 80 to $100 \mathrm{~m}$ typically being within the nitracline. On average about $33 \%$ of the integrated silica production in the upper $160 \mathrm{~m}$ occurred within the nitracline. Combining those observations with the results of our spatial survey suggest that new production by diatoms deep within the euphotic zone is both a widespread and persistent feature in the western Sargasso Sea.

Diatoms growing within the nitracline may be responsible for a significant amount of new production. We used the data of Nelson \& Brzezinski (1996) to 
calculate average integrated silica production rates within the nitracline at the BATS site over 3 yr. That

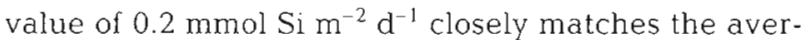
age integrated silica production rate we observed within the nitracline during our spatial survey $(47 \%$ of $0.64=0.3 \mathrm{mmol} \mathrm{Si} \mathrm{m} \mathrm{m}^{-2}$, Table 1). Those rates correspond to an annual production of 73 to $110 \mathrm{mmol} \mathrm{Si} \mathrm{m}^{-2}$ $\mathrm{yr}^{-1}$ or 0.56 to $0.84 \mathrm{~mol} \mathrm{C} \mathrm{m}^{-2} \mathrm{yr}^{-1}$ assuming a Si:C mole ratio of 0.13 in diatoms (Brzezinski 1985). That level of new production is 16 to $24 \%$ of the estimated annual total new production for the region calculated by Jenkins (3.5 mol C m $\mathrm{m}^{-2} \mathrm{yr}^{-1}$; 1988). Brzezinski \& Nelson (1995) estimated that diatoms account for up to $30 \%$ of the annual new production in the Sargasso Sea based on the vertical flux of $\mathrm{BSiO}_{2}$ out of the upper $150 \mathrm{~m}$ at the BATS site. Our estimate of 16 to $24 \%$ is more conservative since it assumes that only diatoms within the nitracline contribute to new production.

Acknowledgements. Thanks to Rob Olson and Penny Chisholm for the opportunity to participate in cruise 206 of the RV 'Oceanus' and to Mark Altabet for inviting M.B. to participate on his cruise aboard the RV 'Weatherbird I' Both groups generously provided data on light intensity, chlorophyll concentration, temperature and nitrate concentration for use in this report. This manuscript benefited from comments by Uta Passow and 3 anonymous reviewers

\section{LITERATURE CITED}

Banahan S, Goering JJ (1986) The production of biogenic silica and its accumulation on the southeastern Bering Sea shelf. Cont Shelf Res 5: 199-213

Brzezinski MA. (1985) The Si:C:N ratio of marine diatoms: interspecific variability and the effect of some environmontal variables. J Phycol 21:347-357

Brzezinski MA, Nelson DM (1995) The annual silica cycle in the Sargasso Sea near Bermuda. Deep Sea Res 42:1215-1237

Brzezinski MA, Nelson DM (1996) Chronic substrate limitation of silicic acid uptake rates in the western Sargasso Sea. Deep Sea Res II 43:437-453

Chisholm SW, Olson RJ, Zettler ER, Goericke R, Waterbury JB, Welschmeyer NA (1988) A novel free-living prochlorophyte abundant in the oceanic euphotic zone. Nature 334 : $340-343$

Goldman JC (1988) Spatial and temporal discontinuities of biological processes in pelagic surface waters. ln: Rothschild BJ (ed) Toward a theory on biological-physical interactions in the world ocean. NATO ASI Series C. Mathematical and physical sciences No. 239

Goldman JC (1993) Potential role of large oceanic diatoms in new primary production. Deep Sea Res 40:159-168

Hulburt EM (1990) Description of phytoplankton and nutrient in spring in the western North Atlantic Ocean. J Plankton Res $12: 1-28$

Jenkins WJ (1988) Nitrate flux into the euphotic zone near Bermuda. Nature 331:521-523
Karl DM, Christian JR, Dore JE, Hebel DV, Letelier RM, Tupas LM, Winn CD (1996) Seasonal and interannual variabiluty in primary production and particle flux at station ALOHA. Deep Sea Res II 43:539-568

Knap AH, Michaels AF, Dow RL, Johnson RJ, Gunderson K Sorensen JC, Close AR, Howes F, Hammer M, Knauer GA, Lohrenz SE, Asper VA, Tuel M, Ducklow H, Quinby $\mathrm{H}$, Brewer P, Bidigare R (1992) Bermuda Atlantic times series data report B-2. U.S. JGOFS Planning and Coordination Office, Woods Hole Oceanographic Institution, Woods Hole, MA

Knap AH, Michaels AF, Dow RL, Johnson RJ, Gunderson K. Sorensen JC, Close AR, Howes F, Hammer M, Knauer GA, Lohrenz SE, Asper VA, Tuel M. Ducklow $H$, Quinby $H$ (1993) Bermuda Atlantic times series data report B-3. U.S. JGOFS Planning and Coordination Office, Woods Hole Oceanographic Institution, Woods Hole, MA

Leynaert A, Nelson DM, Quéguiner B, Tréguer P (1993) The silica cycle in the Antarctic ocean: is the Weddell Sea atypical? Mar Ecol Prog Ser 96:1-15

Malone TC (1980) Size-fractionated primary productivity of marine phytoplankton. In: Falkowski PG (ed) Primary productivity in the sea. Plenum Press, New York, p 301-319

Michaels AF, Knap AH, Dow RL, Gunderson K, Johnson RJ, Sorensen J, Close A, Knauer GA, Lohrenz SE, Asper VA Tuel M, Bidigare R (1994) Seasonal patterns of ocean biogeochemistry at the U.S. JGOFS Bermuda Atlantic time-series study site. Deep Sea Res 41:1013-1038

Murphy LS, Haugen EM (1985) The distribution and abundance of phototrophic ultraplankton in the North Atlantic. Limnol Oceanogr 30:4758

Nelson. DM, Brzezinski MA (1996) Production and vertical transport of biogenic silica in an oligotrophic mid-ocean gyre: a three-year record from the Sargasso Sea near Bermuda. Limnol Oceanogr (in press)

Nelson DM, Goering JJ (1977) A stable isotope tracer method to measure silicic acid uptake by marine phytoplankton. Anal Biochem 78:139-147

Nelson DM. Goering JJ (1978) Assimilation of silicic acid by phytoplankton in the Baja California and the northwest Africa upwelling systems. Limnol Oceanogr 23:508-517

Nelson DM, Goering JJ, Boisseau DW (1981) Consumption and regeneration of silicic acid in three coastal upwelling systems. In: Richards FA (ed) Coastal upwelling. American Geophysical Union, p 242-256

Nelson DM, Gordon LI (1982) Production and pelagic dissolution of biogenic silica in the Southern Ocean. Geochim Cosmochim Acta 46:491-500

Nelson DM, Smith WO (1986) Phytoplankton bloom dynamics of the western Ross Sea ice edge. II. Mesoscale cycling of nitrogen and silicon. Deep Sea Res 33:1389-1412

Nelson DM, Tréguer P, Brzezinski MA, Leynaert A, Quéguiner B (1995) Production and dissolution of biogenic silica in the ocean: revised global estimates, comparison with regional data and relationship to biogenic sedimentation. Global Biogeochem Cycles 9:359-372

Sieracki ME, Verity P, Stoecker DK (1993) Plankton community response to sequential silicate and nitrate depletion during the 1989 North Atlantic spring bloom. Deep Sea Res 40:213-225

Strickland JDH, Parsons TR (1972) A practical handbook of seawater analysis, 2nd edn. Bull Fish Res Board Can 167

Manuscript first received: March 5, 1996

Revised version accepted: July 1, 1996 